\title{
Reduced Acetylcholinesterase (AChE) Activity in Adrenal Medulla and Loss of Sympathetic Preganglionic Neurons in TrkA-Deficient, But Not TrkB-Deficient, Mice
}

\author{
Andreas Schober, ${ }^{1}$ Liliana Minichiello, ${ }^{2}$ Markus Keller, ${ }^{3}$ Katrin Huber, ${ }^{1}$ Paul G. Layer, ${ }^{3}$ José L. Roig-López, ${ }^{4}$ \\ José E. García-Arrarás, ${ }^{4}$ Rüdiger Klein, ${ }^{2}$ and Klaus Unsicker ${ }^{1}$ \\ ${ }^{1}$ Department of Anatomy and Cell Biology III, University of Heidelberg, D-69120 Heidelberg, Germany, ${ }^{2}$ European \\ Molecular Biology Laboratory, Differentiation Programme, D-69117 Heidelberg, Germany, ${ }^{3}$ Department of Zoology, \\ Technical University of Darmstadt, D-64287 Darmstadt, Germany, and 4Department of Biology, University of Puerto Rico, \\ Rio Piedras, Puerto Rico 000931-3360
}

TrkA high-affinity receptors are essential for the normal development of sympathetic paravertebral neurons and subpopulations of sensory neurons. Paravertebral sympathetic neurons and chromaffin cells of the adrenal medulla share an ontogenetic origin, responsiveness to NGF, and expression of TrkA. Which aspects of development of the adrenal medulla might be regulated via TrkA are unknown. In the present study we demonstrate that mice deficient for TrkA, but not the neurotrophin receptor TrkB, show an early postnatal progressive reduction of acetylcholinesterase (AChE) enzymatic activity in the adrenal medulla and in preganglionic sympathetic neurons within the thoracic spinal cord, which are also significantly reduced in number. Quantitative determinations of specific AChE activity revealed a massive decrease $(-62 \%)$ in the adrenal gland and a lesser, but still pronounced, reduction in the thoracic spinal cord $(-40 \%)$. Other markers of the adrenal medulla and its innervation, including various neuropeptides, chromogranin B, secretogranin II, amine transporters, the catecholaminesynthesizing enzymes tyrosine hydroxylase and PNMT, synaptophysin, and L1, essentially were unchanged. Interestingly, AChE immunoreactivity appeared unaltered, too. Preganglionic sympathetic neurons, in contrast to adrenal medullary cells, do not express TrkA. They must, therefore, be affected indirectly by the TrkA knock-out, possibly via a retrograde signal from chromaffin cells. Our results suggest that signaling via TrkA, but not TrkB, may be involved in the postnatal regulation of AChE activity in the adrenal medulla and its preganglionic nerves.

Key words: adrenal gland; spinal cord neurons; acetylcholinesterase; chromaffin cells; neurotrophin receptors; knock-out mice
TrkA is a high-affinity neurotrophin receptor that mediates essential actions of nerve growth factor (NGF) on subsets of sympathetic and sensory neurons as well as CNS forebrain cholinergic neurons (Thoenen and Barde, 1980; Levi-Montalcini, 1987; Barde, 1989; Snider, 1994). In rodents, targeted mutations of the genes coding for TrkA (Smeyne et al., 1994), NGF (Crowley et al., 1994) or blockade of endogenous NGF with neutralizing antibodies (Angeletti et al., 1972; Thoenen, 1972) cause the loss of paravertebral sympathetic neurons, thereby demonstrating the essential roles of TrkA and NGF in their development.

Paravertebral sympathetic neurons and the neuroendocrine chromaffin cells of the adrenal medulla and paraganglia share an origin from the neural crest (cf. Unsicker, 1993), responsiveness to exogenous NGF in vitro and in vivo (Unsicker et al., 1978; Aloe

Received Sept. 9, 1996; revised Nov. 1, 1996; accepted Nov. 11, 1996.

This study was supported by Deutsche Forschungsgemeinschaft (SFB317/C8/D4 SFB269/A2). L.M. is supported by a long-term European Molecular Biology fellowship. J.E.G.A. and J.L.R.L. were funded by the Minority International Research Training program of National Institutes of Health-Fogarty International Center and National Institutes of Health Grant RR-8102-18. We thank Richard Hertel and Martin Barth for their expert technical assistance. We thank Drs. N. Wolf, K Krieglstein, N. Kahane, and C. Kalcheim for sharing unpublished results on adrenal TrkB expression. Antibodies to AChE, L1, chromogranin B, secretogranin II, VMAT-1, and VMAT-2 were generously provided by Drs. J. Massoulié, A. Faissner, W. Huttner, and M. Hannah.

Correspondence should be addressed to Dr. Klaus Unsicker, Department of Anatomy and Cell Biology III, University of Heidelberg, Im Neuenheimer Feld 307, D-69120 Heidelberg, Germany.

Copyright (C) 1997 Society for Neuroscience $\quad 0270-6474 / 97 / 170891-13 \$ 05.00 / 0$ and Levi-Montalcini, 1979; Müller and Unsicker, 1986), and expression of TrkA (Snider, 1994; this study). It is not clear, however, which aspects of development of the adrenal medulla may be regulated via TrkA. Transgenic mice deficient for each of the known members of the Trk receptor family have been generated recently (Klein et al., 1993, 1994; Smeyne et al., 1994) (for review, see Klein, 1994; Snider, 1994). Whether the adrenal medulla is affected in any of these knock-outs has not been reported.

Beyond cell survival, transmitter synthesis, and neurite growth, TrkA-mediated mechanisms have long been known to regulate expression of cell surface molecules as, e.g., neural cell adhesion molecule (N-CAM) (Prentice et al., 1987), NGF-inducible large external protein (NILE) (McGuire et al., 1978), and various proteases (Machida et al., 1989, 1991). Acetylcholinesterase (AChE; E.C. 3.1.1.8) is a prominent intra- and extracellularly located enzyme in cholinergic and many noncholinergic neurons, including chromaffin cells (Lewis and Shute, 1969; Massoulié et al., 1993). Its principal function in cholinergic tissues is the hydrolysis of acetylcholine (Massoulié et al., 1993), but other functions also have been discussed (Small, 1989; Layer and Willbold, 1995). NGF has long been known to regulate in vitro acetylcholinesterase activity in PC12 pheochromocytoma cells and adrenal chromaffin cells (for references, see Discussion).

Adrenal medullary chromaffin cells receive a prominent cholinergic innervation from preganglionic sympathetic neurons, which, in their vast majority, are located in the intermediolateral (IML) column of the thoracic spinal cord (Kesse et al., 1988; Strack et al., 
1988; Pyner and Coote, 1994a,b) (for review, see Parker, 1996). Nerve fibers, presumably of preganglionic origin, can be found in the rat adrenal gland as early as embryonic day (E) 15 (Millar and Unsicker, 1981). These nerve fibers become AChE-positive during the first postnatal week (Millar and Unsicker, 1981), and a functional innervation of chromaffin cells, i.e., discharge of catecholamines by neurogenic stimuli, commences in rat at the end of the first week (Slotkin, 1986; Parker et al., 1988).

The present study shows that mice deficient in the TrkA, but not the TrkB receptor, display a significant reduction in AChE activity in the adrenal medulla and its preganglionic innervation. In addition, numbers of preganglionic sympathetic neurons in the IML column of the spinal cord are reduced significantly in TrkAdeficient, but not TrkB-deficient, animals.

\section{MATERIALS AND METHODS}

TrkA- and TrkB-deficient (-/-) and wild-type $(+/+)$ mice aged $0-12 \mathrm{~d}$ were used. Numbers of animals per phenotype were postnatal (P) P0, $n=$ 15; $\mathrm{P} 3, n=15 ; \mathrm{P} 7, n=25$; and $\mathrm{P} 12, n=25$. The TrkA and TrkB knock-out mice were generated by breeding heterozygous mutant mice kept on a mixed 129/sv $\times$ C57BL/6 background. Standard procedures (Laird et al., 1991) were used for the genomic DNA extraction from tail biopsies of mice. We determined TrkA and TrkB genotypes by PCR amplification using, respectively, a common $5^{\prime}$ primer (5'-GACCCTGCACTGTCGAGTTTGC-3') and either a $3^{\prime}$ primer for wild-type allele (5'-CGGACCTCAGTGTTGGAGAGCTGG-3') or a primer from the pgk-1 promoter of the neo cassette (5'-GCTCCCGATTCGCAGCGCATCG-3') and a common $5^{\prime}$ primer (5'-TCGCGTAAAGACGGAACATGATCC-3') and either a $3^{\prime}$ primer for the wild-type allele $\left(5^{\prime}\right.$-AGACCTGATGAGTGGGTCGCC- $\left.3^{\prime}\right)$ or a $3^{\prime}$ primer from the pgk-1 promoter of the neo cassette (5'-GATGTGGAATGTGTGCGAGGCC-3'). The PCR product was analyzed on a $1.5 \%$ agarose gel.

In situ hybridization of TrkA $m R N A$. Wild-type mice (P6, $n=2 ; \mathrm{P} 12$, $n=2$; adult, $n=2$ ) were anesthetized and perfused with $4 \%$ paraformaldehyde (PFA). Adrenal glands were dissected, post-fixed (12 hr), and processed for paraffin embedding. Deparaffinized sections $(7 \mu \mathrm{m})$ were rehydrated and washed in $0.83 \% \mathrm{NaCl}$ and in PBS. Then sections were post-fixed for $10 \mathrm{~min}$ in $4 \%$ PFA, washed two times in PBS, and incubated for $30 \mathrm{~min}$ with proteinase $\mathrm{K}(20 \mu \mathrm{g} / \mathrm{ml}$ in $50 \mathrm{~mm}$ Tris $/ 0.5 \mathrm{M}$ EDTA $)$, followed by washes in PBS $/ 0.2 \%$ glycine and PBS. Sections again were post-fixed for $10 \mathrm{~min}$ in $4 \%$ PFA, rinsed in PBS and distilled water, and thereafter incubated for $10 \mathrm{~min}$ in $1.3 \%$ triethanolamine $/ 0.31 \%$ acetic anhydrate in $0.05 \mathrm{~N} \mathrm{HCl}$. Finally, slides were washed in PBS and $0.83 \%$ $\mathrm{NaCl}$, dehydrated, and air-dried.

Hybridization was performed in $50 \%$ formamid, $0.3 \mathrm{M} \mathrm{NaCl}, 20 \mathrm{mM}$ Tris, $\mathrm{pH} 7.5,5 \mathrm{~mm}$ EDTA, $10 \%$ dextran sulfate, $1 \times$ Denhardt's solution, $0.5 \mathrm{mg} / \mathrm{ml}$ total yeast tRNA, and $10 \mathrm{~mm}$ dithiothreitol (DTT) with $1 \times 10^{7}$ $\mathrm{cpm}$ of ${ }^{35} \mathrm{~S}$-UTP-labeled cRNA probe, which was transcribed with T7 polymerase from $\mathrm{pRB} 6$, a $\mathrm{pBS} \mathrm{KS}^{-}$carrying a $398 \mathrm{bp}$ insert from the TrkA receptor. Sections were hybridized overnight at $60^{\circ} \mathrm{C}$ in a humidified chamber. On the next day slides were washed for $1 \mathrm{hr}$ at $55^{\circ} \mathrm{C}$ in $2 \times$ SSC, $50 \%$ formamid, and $10 \mathrm{~mm}$ DTT and then for $1 \mathrm{hr}$ at $55^{\circ} \mathrm{C}$ in $2 \times$ SSC, $50 \%$ formamid, and $10 \mathrm{~mm}$ DTT. Subsequently, slides were rinsed three times for $10 \mathrm{~min}$ at $37^{\circ} \mathrm{C}$ in NTE buffer $(0.5 \mathrm{M} \mathrm{NaCl}, 10 \mathrm{~mm}$ Tris, and $5 \mathrm{~mm}$ EDTA) and then incubated for $30 \mathrm{~min}$ at $37^{\circ} \mathrm{C}$ with $20 \mu \mathrm{g} / \mathrm{ml}$ RNase A in NTE buffer. After a 15 min processing in NTE buffer, slides were washed for $1 \mathrm{hr}$ at $55^{\circ} \mathrm{C}$ in $2 \times \mathrm{SSC}, 50 \%$ formamid, and $10 \mathrm{~mm}$ DTT and then for $15 \mathrm{~min}$ at room temperature (RT) in $0.2 \times$ SSC. After dehydration, sections were air-dried, dipped in Kodak NTB-2 emulsion (diluted 1:1 in water), exposed for 4 weeks at $4^{\circ} \mathrm{C}$, developed, fixed, and counterstained with hematoxylin.

AChE histochemistry. Staining was performed according to a modification of the direct coloring thiocholine method of Karnovsky and Roots (1964) for histochemical detection of AChE activity (Andrä and Lojda, 1986). Adrenal glands and the full length of the thoracic spinal cord were removed from perfused TrkA $(-/-)$, TrkB $(-/-)$, and wild-type $(+/+)$ animals (4\% PFA in phosphate buffer, $\mathrm{pH} 7.4$ ), cryoprotected (30\% sucrose), frozen on dry ice, and cut into $20-\mu \mathrm{m}$-thick sections. Sections were mounted on slides and stained for $1 \mathrm{hr}$ at $37^{\circ} \mathrm{C}$ in the following solution $(60 \mathrm{ml}): 30.0 \mathrm{mg}$ of acetylthiocholine iodide (Serva Feinbiochemica, Heidelberg, Germany), $44.4 \mathrm{ml}$ of $0.1 \mathrm{~m}$ Tris-maleate buffer, $\mathrm{pH}$ 5.0 (containing $0.1 \%$ Triton X-100), $6.0 \mathrm{ml}$ of $0.4 \mathrm{M}$ sodium citrate, $6.0 \mathrm{ml}$

\begin{tabular}{lll}
\hline \multicolumn{2}{l}{ Table 1. Polyclonal primary antibodies used for immunocytochemistry } \\
Antibody & Dilution & Reference \\
\hline Neuropeptide Y & $1: 500$ & García-Arrarás et al., 1992 \\
Somatostatin & $1: 3000$ & García-Arrarás et al., 1984 \\
Met-enkephalin & $1: 500$ & Dr. Barreto-Estrada, unpublished data \\
VIP & $1: 1000$ & García-Arrarás et al., 1987 \\
Galanin & $1: 1000$ & Díaz-Miranda et al., 1996 \\
Synaptophysin & $1: 100$ & Sigma-Aldrich GmbH, Germany \\
AChE & $1: 1000$ & Marsh et al., 1984 \\
L1 & $1: 1000$ & Faissner et al., 1985 \\
TH & $1: 500$ & Eugene Tech, OR \\
PNMT & $1: 1000$ & Incstar, Stillwater, OK \\
Chromogranin B & $1: 500$ & Rosa et al., 1985 \\
Secretogranin II & $1: 200$ & Rosa et al., 1985 \\
VMAT-1 & $1: 100$ & Dr. Hannah, unpublished data \\
VMAT-2 & $1: 2000$ & Dr. Hannah, unpublished data \\
\hline
\end{tabular}

of $0.12 \mathrm{M}$ copper sulfate, $3.0 \mathrm{ml}$ of $0.16 \mathrm{M}$ potassium ferricyanide, and 0.6 $\mathrm{ml}$ of $10^{-3} \mathrm{M}$ tetraisopropylpyrophosphoramide (iso-OMPA; Sigma, St. Louis, MO). Sections from knock-out and wild-type animals were always stained in parallel.

Immunocytochemistry. Perfusion, fixation, and preparation of sections were performed as described above. Cryostat sections (14, $20 \mu \mathrm{m})$ were mounted on gelatin-coated slides, dried at RT (for $30 \mathrm{~min}$ ), and placed in $0.1 \mathrm{M}$ phosphate buffer (PB), pH 7.4. Nonspecific bindings were blocked by preincubation with $5 \%$ normal goat serum and $0.1 \%$ Triton X-100 in PB for $1 \mathrm{hr}$ at RT. Sections were immunostained as follows: (1) incubation with primary antiserum (for details, see Table 1) and diluted in PB (containing $2 \%$ normal goat serum, $1 \%$ bovine serum albumin, and $0.1 \%$ Triton X-100) for $12 \mathrm{hr}$ at RT; (2) incubation with Cy3-conjugated goat anti-rabbit IgG (Dianova, Hamburg, Germany) and diluted 1:2000 in PB for $1 \mathrm{hr}$ at RT. Controls were performed by using rabbit normal serum or by omitting the respective antiserum. Finally, all sections were rinsed three times in PB, dried, and embedded in Kaiser's glycerol gelatin.

Western blot analysis. Fresh adrenal glands from wild-type $(+/+)$, TrkA $(+/-;-/-)$, and TrkB $(-/-)$ animals (P6; pooled from two animals per genotype) were homogenized in the presence of detergent, and proteins were separated on a $7.5 \%$ acrylamide-containing SDS-gel $(2 \mu \mathrm{g} /$ lane $)$ in a mini chamber (Bio-Rad, Richmond, CA). After transfer to nitrocellulose, the proteins were incubated with a monoclonal AChE antibody (diluted 1:2500; Transduction Laboratories, Lexington, KY) overnight. The primary antibody was visualized via a mouse Vectastain kit (Vector Laboratories, Burlingame, CA). Finally, the bands were analyzed by computer densitometry (ImageQuant).

Determination of AChE activity. AChE activity was determined in homogenates of fresh adrenal glands (pooled from three animals) and the thoracic spinal cord by a microtiter plate-adapted modification of the Ellman method (Ellman et al., 1961) at $405 \mathrm{~nm}(20 \mathrm{~min})$. The substrate concentration for acetylthiocholine iodide was $1.5 \mathrm{~mm}$. To inhibit any butyrylcholine esterase activity, we determined the AChE activities in the presence of $0.1 \mathrm{~mm}$ iso-OMPA. The protein content in each of the homogenates was quantified according to the Bradford method (1976), using bovine serum albumin as a standard. Results were given as mean values \pm SEM and tested for significance by Student's $t$ test.

Determinations of catecholamines. Catecholamines of single adrenal glands (P6) were quantified by high performance liquid chromatography (HPLC) and electrochemical detection essentially as described by Müller and Unsicker (1981). The amounts of catecholamines were averaged and the SEM was calculated. Statistical significance was determined by Student's $t$ test.

Cell counts. Nissl-stained thoracic spinal cord sections (TrkA $-/-, n=$ 4; $\operatorname{TrkB}-/-, n=3$; wild-type $+/+, n=3$ ) were used for determining numbers of sympathetic preganglionic neurons (100 adjacent cross sections per animal, $20 \mu \mathrm{m}$, segments T8-T10). To identify sympathetic preganglionic neurons reliably, we counterstained Nissl-stained sections weakly by AChE histochemistry as described above. Only neurons with a clearly visible nucleus were counted, and the total number of labeled neurons was estimated according to Abercrombie's formula (Konigsmark, 1970). Results were given as mean values SD and tested for statistical significance by Student's $t$ test. 

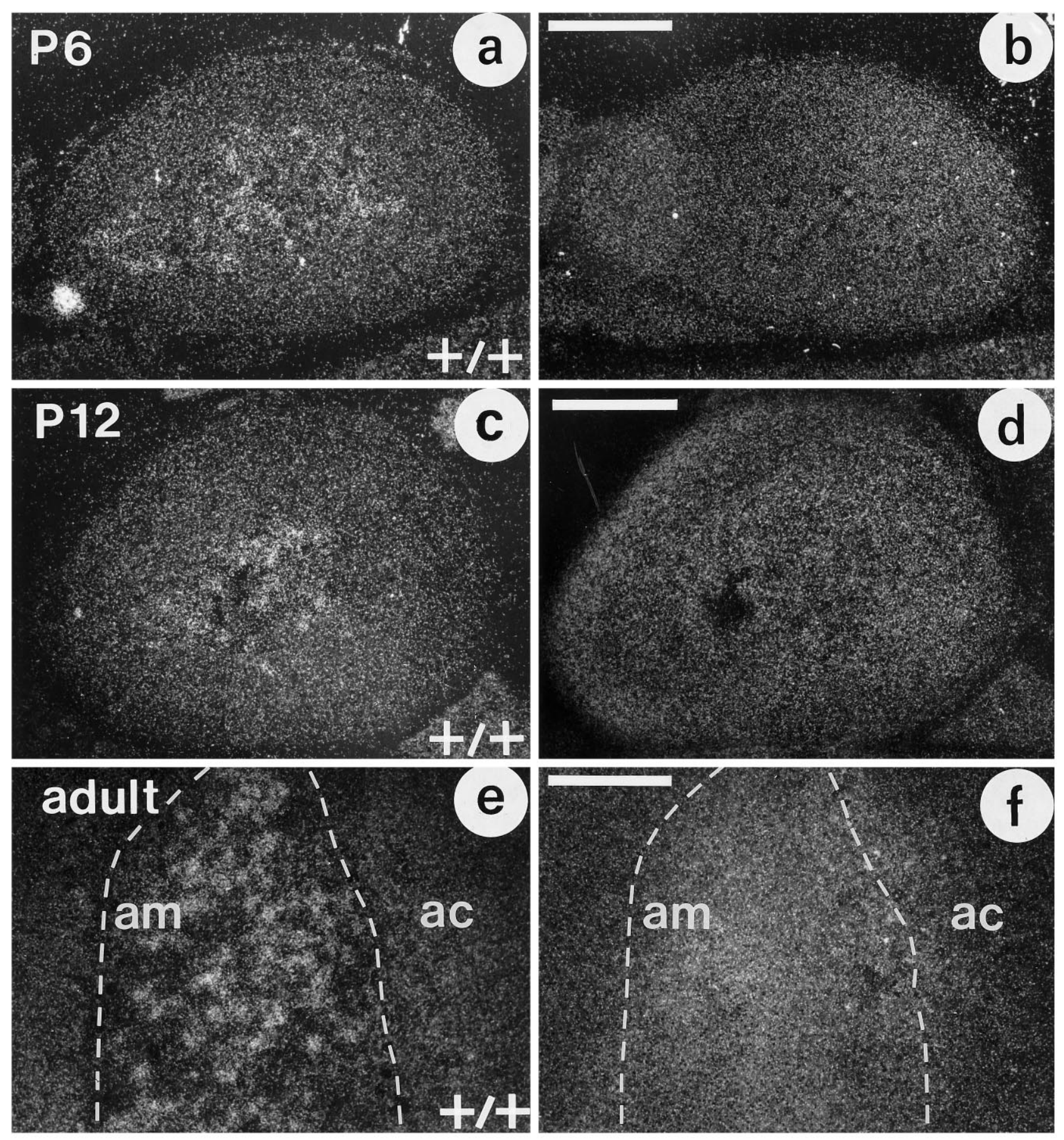

\section{TrkA antisense}

sense control

Figure 1. In situ hybridization of TrkA mRNA using an antisense probe $(a, c, e)$ and a sense control $(b, d, f)$ in the P6, P12, and adult mouse adrenal glands shows specific labeling of the adrenal medulla $(\mathrm{am})$, which is particularly prominent over clusters of chromaffin cells. The surrounding cortex (ac) shows background labeling. Scale bars, $200 \mu \mathrm{m}$.

\section{RESULTS}

\section{TrkA is expressed in the developing and adult mouse} adrenal medulla

To establish that NGF responsiveness and high-affinity binding of NGF to chromaffin cells (for references, see Discussion) reflect an expression of TrkA, we performed in situ hybridization studies. Figure 1 shows the localization of TrkA mRNA and correspond- ing sense controls in mouse adrenal glands at postnatal ages P6 (Fig. 1a,b), P12 (Fig. 1c,d), and in the adult (Fig. 1e,f). During all postnatal ages, labeling was confined to the center portion of the gland, consistent with the expression of TrkA within the adrenal medulla and its chromaffin cells. No signal was detectable at P0 (data not shown). Adrenal chromaffin cells did not express TrkB at these ages in mice (data not shown). 


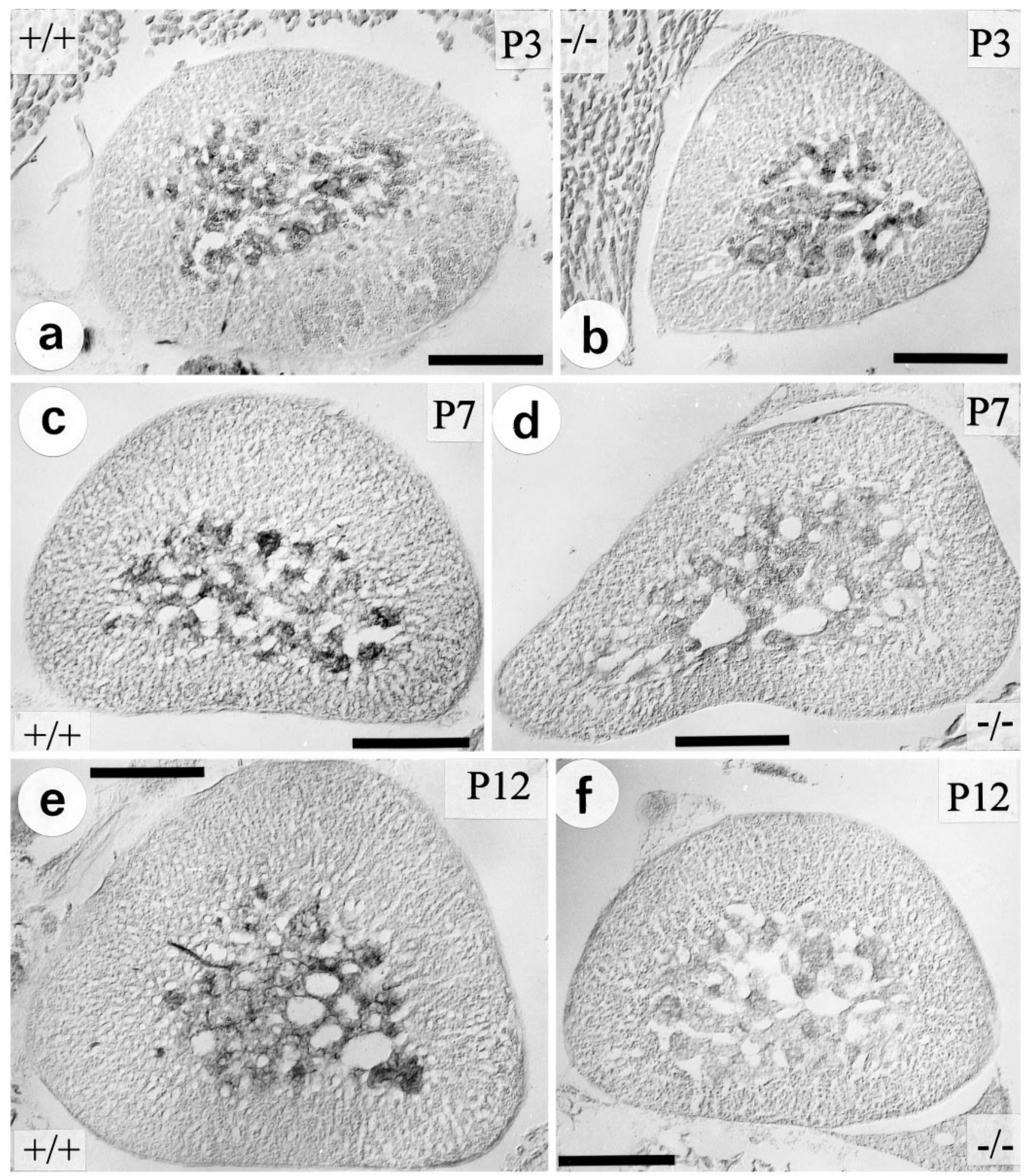

Figure 2. Localization of AChE activity by histochemistry in the adrenal gland. At $\mathrm{P} 3(a, b)$, there are no differences in AChE activity and localization between wild-type $(+/+)$ and TrkA knock-out $(-/-)$ animals. The gross morphology of the adrenal gland apparently is unchanged in the knock-outs. At $\mathrm{P} 7(c, d)$ and $\mathrm{P} 12(e, f), \mathrm{AChE}$ activity is reduced in TrkA-deficient mice $(d, f)$, as compared with wild-type $(c, e)$ animals. Scale bars, $200 \mu \mathrm{m}$.

\section{AChE histochemical staining of the adrenal medulla is reduced in TrkA (-/-) mice}

Figure 2 illustrates the temporal development of histochemically demonstrable AChE activity in the early postnatal adrenal gland of wild-type mice (+/+; Fig. 2a,c,e) and animals deficient for TrkA (-/-; Fig. 2b,d,f). At postnatal days P0 (data not shown) and P3 (Fig. 2a,b), there were no detectable differences in AChE staining between wild-type and TrkA knock-out mice. At these 


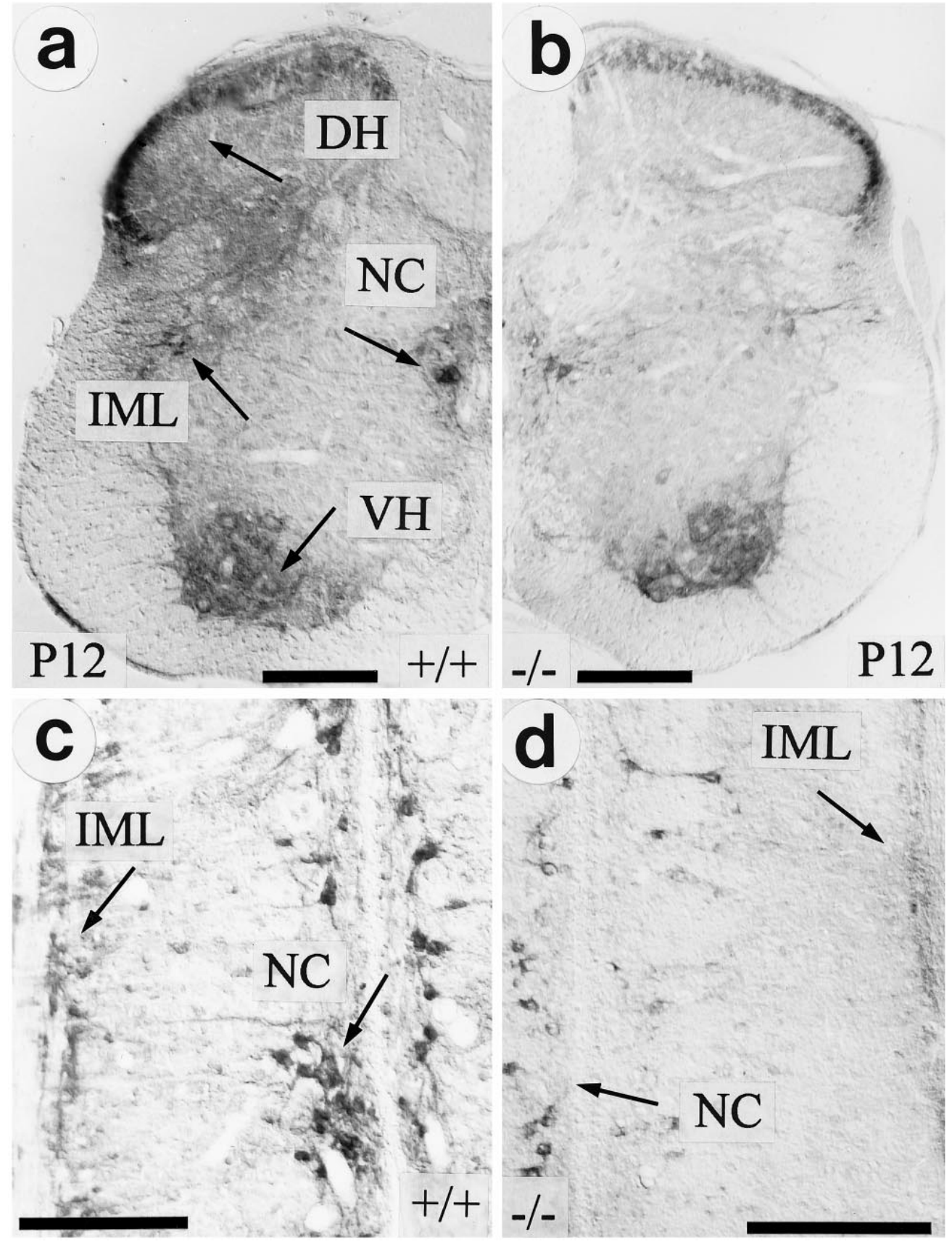

Figure 3. Localization of AChE activity by histochemistry in thoracic spinal cord. In TrkA-deficient mice $(b)$, there is a strong reduction of $\mathrm{AChE}$ activity in autonomic nuclei as well as in the superficial layers of the dorsal horn $(D H)$, as compared with the wild-type $(a) . I M L$, Intermediolateral column; $N C$, nucleus centralis; $V H$, ventral horn. $c$, Longitudinal section of thoracic spinal cord (T7-T10) showing AChE-positive preganglionic sympathetic neurons located in $I M L$ and $N C$ of a wild-type animal. $d$, Both the number of reactive neurons and their AChE activity are decreased dramatically in TrkA knock-out mice. Scale bars, $200 \mu \mathrm{m}$. early ages, AChE activity was very weak but clearly confined to the adrenal medulla and nerve fibers traversing the cortex. (Fig. 2a,b). In wild-type animals (Fig. 2c,e) AChE activity clearly was increased at P7 and P12, as compared with P3, and associated with cells, fiber bundles, and delicate strands of axons innervating the adrenal medulla. In TrkA $(-/-)$ mice a dramatic decrease in AChE histochemical staining became apparent at P7 (Fig. 2d), resulting in an almost complete loss of adrenal AChE staining in P12 animals (Fig. 2f).

\section{AChE histochemical staining of preganglionic sympathetic neurons, but not motoneurons, in the spinal cord is reduced in TrkA (-/-) mice}

To investigate whether the reduction in AChE activity of adrenal medullary nerve fibers in TrkA $(-/-)$ mice was accompanied by a decrease of AChE activity within the perikarya of these neurons and specific for this neuron population, we studied the thoracic spinal cord, where these neurons are located in the IML column (Strack et al., 1988). Figure $3 a-d$ shows that within the thoracic spinal cord of TrkA (-/-) mice (P12) AChE staining intensity clearly was reduced, as compared with wild-type specimens. This reduction was very pronounced in cell bodies of preganglionic sympathetic neurons located in the IML column and in nerve fibers within the dorsal horn. AChE staining in motoneurons appeared to be unaffected. As in the adrenal medulla, alterations in spinal cord AChE staining became apparent at P7 and progressed toward P12 (data not shown).

\section{AChE histochemical staining is unaltered in adrenal gland and spinal cord IML neurons of TrkB $(-/-)$ mice}

To exclude that alterations in AChE activity seen in adrenal gland and spinal cord of TrkA-deficient mice were unspecific, 


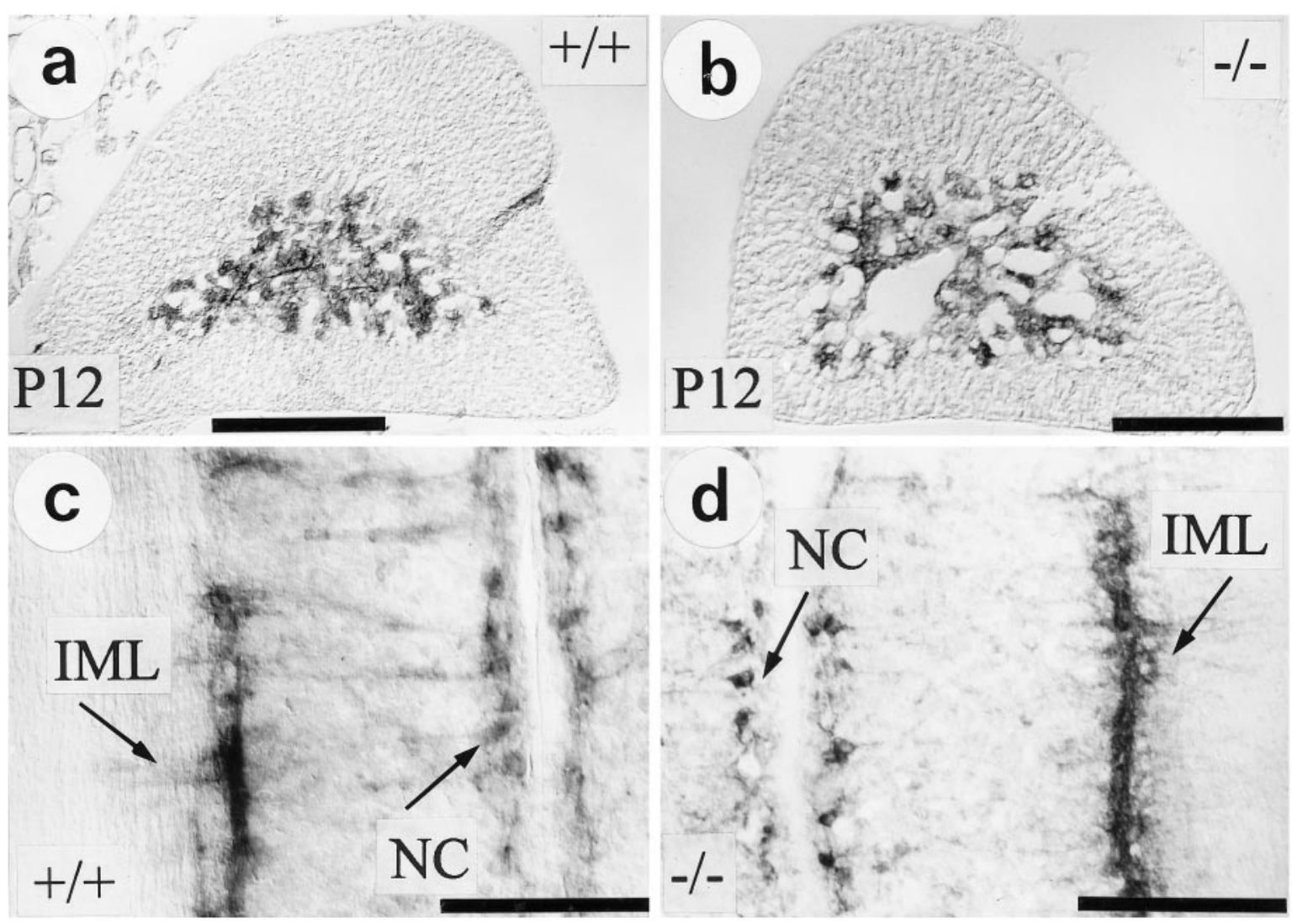

Figure 4. AChE histochemical staining in adrenal medulla $(a, b)$ and thoracic spinal cord (T7-T10; $c, d)$ of TrkB-deficient mice, as compared with wild-type littermates. At P12 there is no difference in AChE activity and localization detectable between TrkB knock-outs $(b, d)$ and wild-type controls $(a, c) . I M L$, Intermediolateral column; $N C$, nucleus centralis. Scale bars, $200 \mu \mathrm{m}$.

resulting from severe illness of these animals, we investigated TrkB (-/-) mice that also died during the early postnatal period. Patterns and intensities of AChE staining in adrenal medullary nerve fibers and thoracic spinal cord IML neurons were undistinguishable in $\operatorname{TrkB}(-/-)$ and wild-type $(+/+)$ mice (Fig. $4 a-d$ ). This result suggests that TrkA, but not TrkB, is involved in the postnatal regulation of $\mathrm{AChE}$ activity in preganglionic sympathetic neurons of the spinal cord.

\section{Quantitative determination of specific AChE activity reveals a pronounced reduction in adrenal gland and thoracic spinal cord homogenates of TrkA $(-/-)$ mice, but not in TrkB-deficient mice}

Quantitative analysis of AChE activity in homogenates from whole adrenal glands provided evidence that the decrease in AChE staining intensity seen in TrkA $(-/-)$ mice was, in fact, attributable to a substantial reduction in $\mathrm{AChE}$ activity $(\mathrm{P} 7$; $-62 \%$ relative to wild-type littermates, Fig. $5 a$ ). In the thoracic spinal cord of the same animals, a $40 \%$ decrease in specific AChE activity could be demonstrated (Fig. $5 b$ ). In adrenal glands and thoracic spinal cords of TrkB knock-outs, the specific AChE activity was not altered significantly (Fig. $5 a, b$ ).

\section{Chromaffin cell-associated markers detected by immunocytochemistry are not changed overtly in TrkA $(-/-)$ and TrkB (-I-) mice}

To monitor other putative deficits of adrenal medullary development in TrkA knock-outs, we used immunocytochemistry with antibodies to a number of markers associated with chromaffin cells and their preganglionic nerve fibers (see Table 2). Neuropep- tide Y (NPY) immunoreactivity was present in most, if not all, adrenal chromaffin cells of wild-type mice as well TrkA- and TrkB-deficient animals at P0, P7, and P12. There was a minor, yet inconsistent, increase in the intensity of immunofluorescence in the knock-out animals (Fig. $6 c, d$ ). Subpopulations of chromaffin cells displayed immunoreactivities for somatostatin, metenkephalin, and galanin, which were weak or nonexistent at P0 and P6 but clearly apparent at P12, with no notable differences between wild-type and knock-out animals. Immunoreactivities for synaptophysin and the adhesion molecule L1 were associated with fibers and varicosities surrounding chromaffin cells and cell clusters. Both the distributional patterns and fluorescence intensities were unaltered in the knock-out animals. Likewise, patterns and intensities of the immunoreactivities for tyrosine hydroxylase (TH) and phenylethanolamine $N$-methyltransferase (PNMT), chromogranin B, secretogranin II, and the vesicular monoamine transporters I and II (VMAT-1, VMAT-2) were not affected by the TrkA and TrkB deficits.

\section{Immunocytochemical staining of AChE is unaltered in adrenal medullae of TrkA (-I-) mice}

Given the lack of alterations in any of the above axonal and neuroendocrine markers, we investigated whether changes in AChE staining using enzyme activity as an indicator were reflected in alterations of immunocytochemically demonstrable AChE protein. As shown in Figure $6 a, b$, the polyclonal antibody to AChE clearly revealed the localization of $\mathrm{AChE}$ in nerve fibers supplying adrenal medullary cells without showing any differences in the intensities of the immunocytochemical staining. These results suggest that the 


\section{(a) Determination of AChE-Activity}
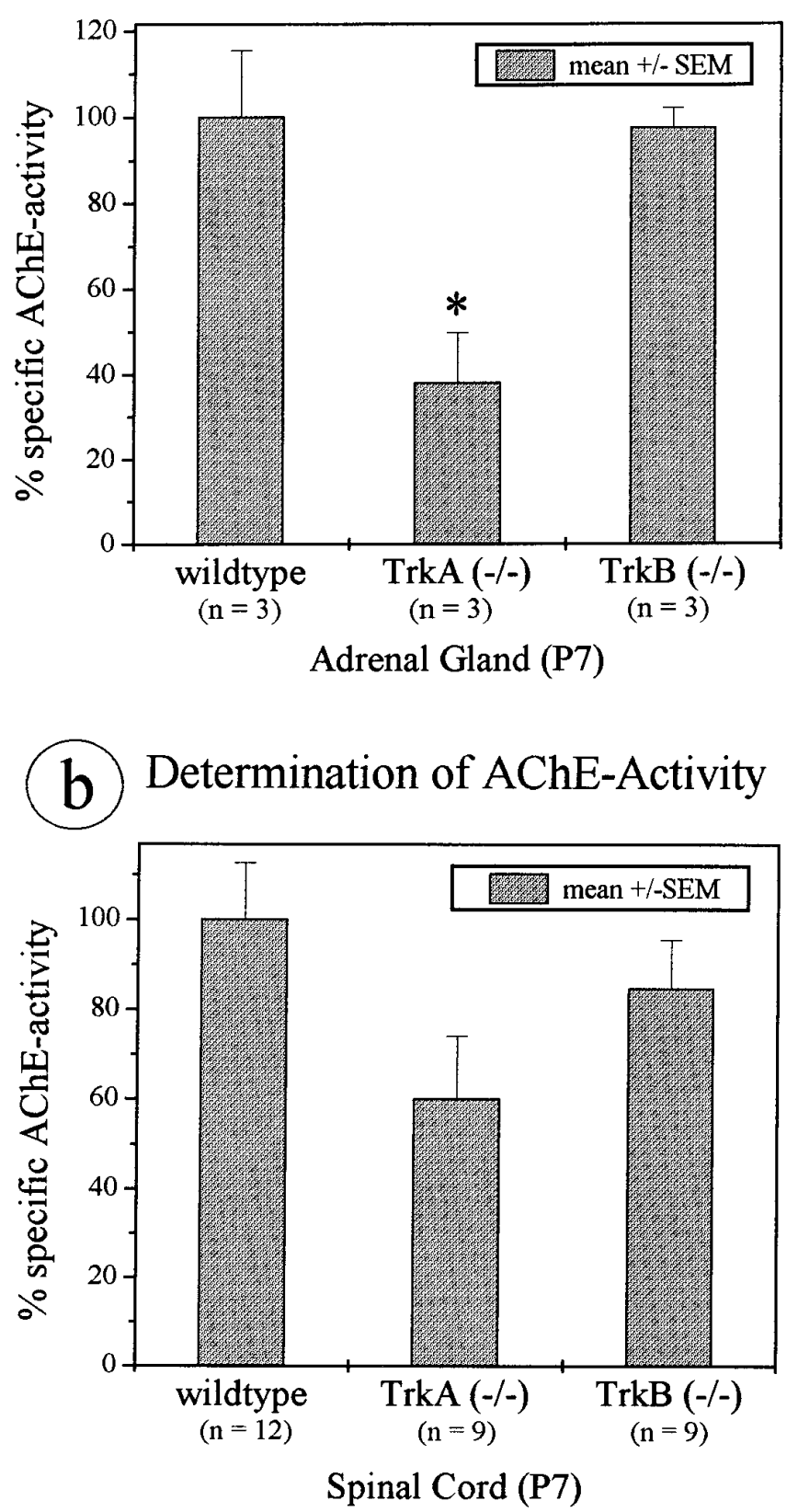

Figure 5. Biochemical determination of AChE activity in homogenates. At P7, specific AChE activity is decreased significantly $(-62 \%)$ in the adrenal gland $(a)$ of TrkA knock-out animals $(+/+, n=3 ;-/-, n=3$; $\left.{ }^{*} p>0.05\right)$. In thoracic spinal cord $(b)$, there is a $40 \%$ reduction of specific AChE activity $(+/+, n=12 ;-/-, n=9)$ relative to the wild-type. In contrast, levels of AChE activity of adrenal glands and spinal cords in TrkB knock-out animals are not altered significantly. Error bars, \pm SEM.

TrkA receptor knock-out clearly affects the activity of the enzyme, without affecting the presence of preganglionic nerve fibers within the adrenal gland. Moreover, expression of the protein and enzyme activity seems to be differentially regulated.

\section{Western blot analysis of AChE protein}

To support further the notion that AChE immunoreactivity in adrenal glands of TrkA $(-/-)$ animals was primarily unchanged,

\begin{tabular}{|c|c|c|c|c|}
\hline & Structure labeled & $\begin{array}{l}\text { Wild- } \\
\text { type }\end{array}$ & $\begin{array}{l}\text { TrkA } \\
(-/-)\end{array}$ & $\begin{array}{l}\text { TrkB } \\
(-/-)\end{array}$ \\
\hline \multicolumn{5}{|l|}{ Neuropeptides } \\
\hline Neuropeptide Y & $\begin{array}{l}\text { Chromaffin cell sub- } \\
\text { populations ( } 2 \text { ) }\end{array}$ & ++ & +++ & +++ \\
\hline Somatostatin & $\begin{array}{l}\text { Chromaffin cell sub- } \\
\text { population }\end{array}$ & + & + & + \\
\hline Met-enkephalin & $\begin{array}{l}\text { Chromaffin cell sub- } \\
\text { population }\end{array}$ & + & + & + \\
\hline Galanin & $\begin{array}{l}\text { Chromaffin cell sub- } \\
\text { population }\end{array}$ & ++ & ++ & ++ \\
\hline \multicolumn{5}{|l|}{ Innervation } \\
\hline Synaptophysin & Fiber innervation & ++ & + & + \\
\hline L1 & $\begin{array}{l}\text { Fiber innervation and } \\
\text { extracellular labeling }\end{array}$ & ++ & ++ & ++ \\
\hline \multicolumn{5}{|l|}{$\begin{array}{l}\text { Catecholamine syn- } \\
\text { thesizing enzymes }\end{array}$} \\
\hline TH & $\begin{array}{l}\text { Chromaffin cell sub- } \\
\text { populations ( } 2 \text { ) }\end{array}$ & +++ & +++ & +++ \\
\hline PNMT & $\begin{array}{l}\text { Chromaffin cell sub- } \\
\text { population }\end{array}$ & ++ & ++ & ++ \\
\hline \multicolumn{5}{|l|}{ Vesicular } \\
\hline Chromogranin B & $\begin{array}{l}\text { Chromaffin cell sub- } \\
\text { population }\end{array}$ & ++ & + & + \\
\hline Secretogranin II & $\begin{array}{l}\text { Chromaffin cell sub- } \\
\text { population }\end{array}$ & ++ & ++ & ++ \\
\hline VMAT-1 & All chromaffin cells & + & + & + \\
\hline VMAT-2 & $\begin{array}{l}\text { Chromaffin cell sub- } \\
\text { population }\end{array}$ & + & + & + \\
\hline
\end{tabular}

*Denotes the apparent degree of labeling: +++ strong, ++ moderate, + weak.

we performed Western blot analysis. As shown in Figure 7, the authentic $68 \mathrm{kDa}$ band of $\mathrm{AChE}$ is equally prominent in homogenates from wild-type, TrkA hetero- and homozygotes, and TrkB homozygote mice. Densitometric analysis revealed a $3.2 \%$ decrease of the band from TrkA $(-/-)$ mice, as compared with wild-type littermates.

\section{Cell counts reveal a reduction in IML neuron numbers in TrkA-deficient, but not in TrkB-deficient, mice}

Cell counts performed on double-stained (Nissl/AChE) serial cryosections (100 adjacent cross sections/animal) through thoracic spinal cord levels T8-T10 of TrkA-deficient mice revealed a reduction in IML neuron numbers by $41.5 \%$, as compared with wild-type controls (Figs. 8, 9). In contrast, the number of IML neurons in TrkB-deficient mice was not affected (Figs. 8, 9).

\section{Catecholamines are reduced in adrenal glands of TrkA $(-/-)$ mice}

To investigate whether the chronic loss of AChE activity in TrkA-deficient animals had an impact on the catecholamine storage and secretion of chromaffin cells, we determined the catecholamines adrenaline and noradrenaline by HPLC-amperometric detection. As shown in Figure 10, there was a significant reduction in the medullary levels of both amines (noradrenaline, $-63.5 \%$; adrenaline, $-70.7 \%$ ), probably because of the prolonged activation of catecholamine secretion by acetylcholine at reduced activity of the hydrolyzing enzyme. 

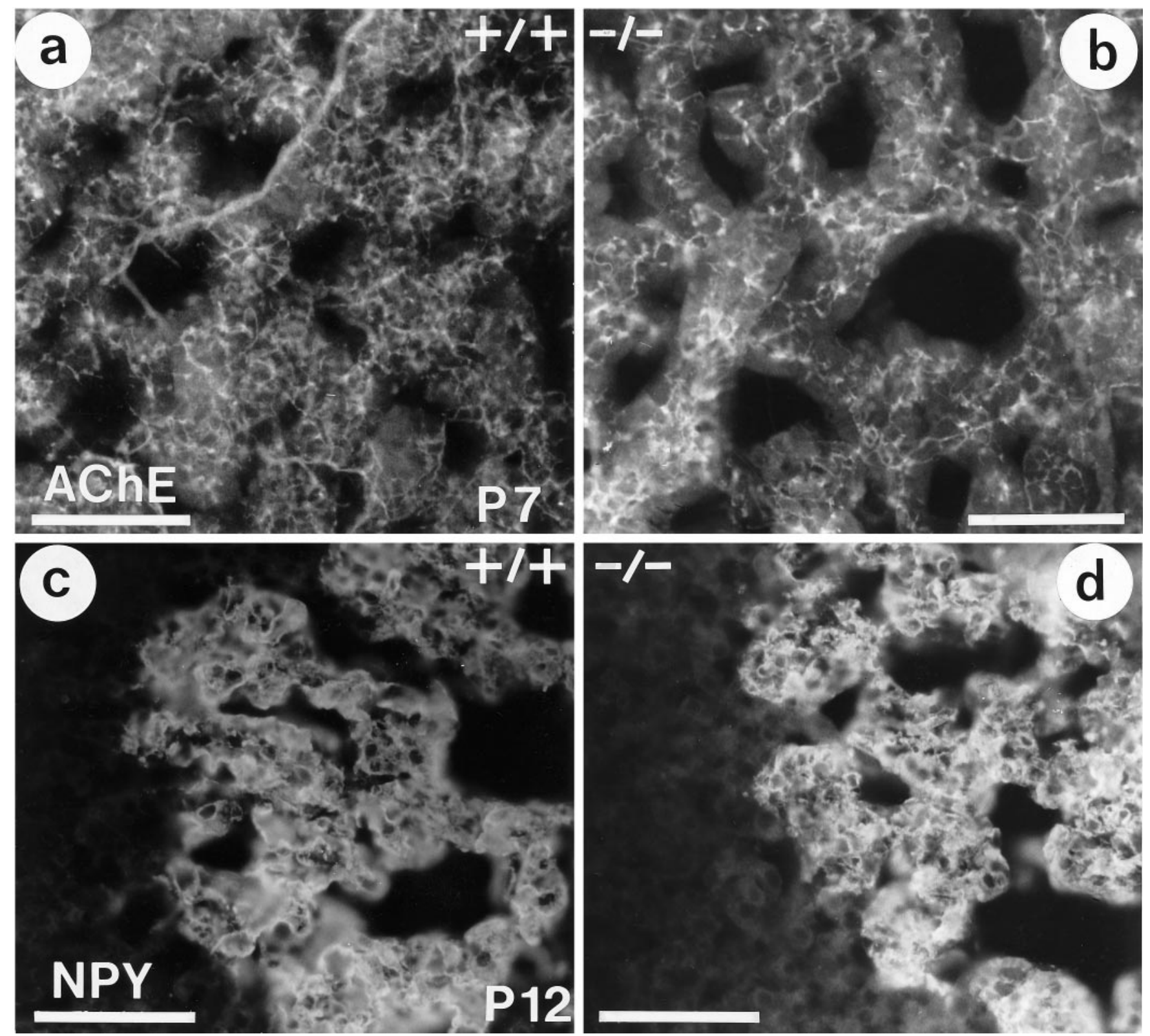

Figure 6. AChE-immunoreactive nerve fibers $(a, b)$ and NPY immunoreactivity $(c, d)$ in the adrenal medulla. At P7 (a,b), density and distribution pattern of AChE-immunostained fibers are not distinguishable in wild-type $(a)$ and TrkA knock-out mice $(b)$. NPY immunoreactivity in chromaffin cells is increased slightly in knock-out, as compared with wild-type, mice at P12. Scale bars, $100 \mu \mathrm{m}$.

\section{DISCUSSION}

The present results add a novel feature to the previously established TrkA $(-/-)$ phenotype, a severe deficit within adrenal gland and preganglionic sympathetic spinal cord neurons regarding the activity of $\mathrm{AChE}$, an enzyme with a well documented crucial role in terminating transmitter actions at cholinergic synapses (for review, see Massoulié et al., 1993). The evidence that the TrkA knock-out affects AChE activity is based on a specific histochemical staining technique (Andrä and Lojda, 1986) and a quantitative photometric method for determining specific $\mathrm{AChE}$ activity (Ellman et al., 1961) in homogenates. AChE staining pattern and intensity reflect the quantitative distribution of AChE activity, because there is a linear correlation between enzyme activity quantified photometrically and staining intensity (Andrä and van Duijn, 1985). The deficit in AChE activity seen in adrenal gland and spinal cord of TrkA $(-/-)$ mice fails to correlate with an overt change in the immunocytochemically demonstrable $\mathrm{AChE}$ and $\mathrm{AChE}$ protein detectable in Western blots, suggesting that AChE activity is compromised more severely than AChE protein expression. This adds to the growing evidence that a pool of inactive AChE protein can be activated post-translationally in an environment-dependent manner (for review, see Massoulié et al., 1993; Layer and Willbold, 1995). Uncompromised AChE protein expression in the adrenal gland of TrkA $(-/-)$ mice is also in accord with an unimpaired localization of synaptophysin within the adrenal gland.

The neuroendocrine chromaffin cells of the adrenal medulla and sympathetic neurons share an ontogenetic origin from the neural crest (cf. Unsicker, 1993) and many structural and functional features, including a prominent cholinergic innervation 


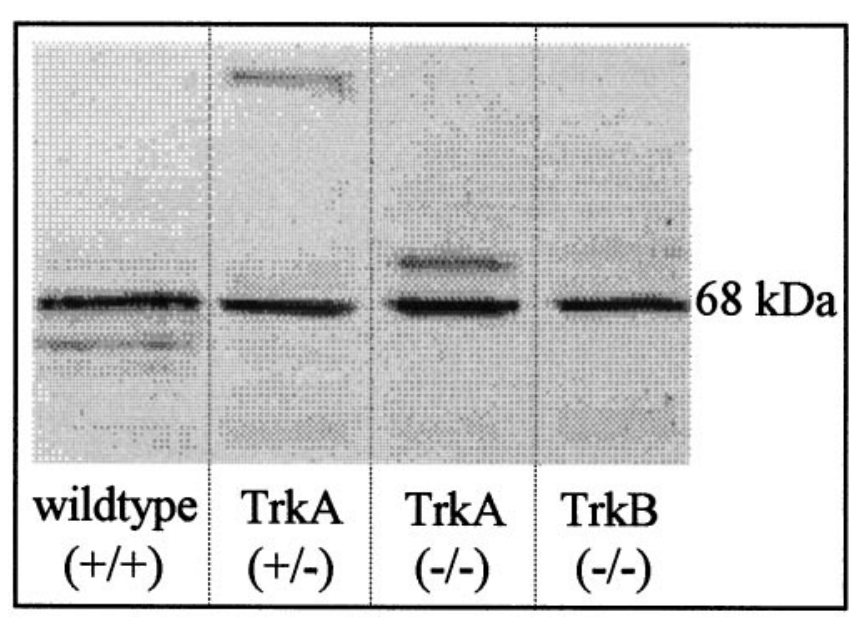

Figure 7. Western blot analysis showing immunoreactive $68 \mathrm{kDa}$ AChE protein in adrenal glands of P6 wild-type, TrkA hetero- and homozygote, and TrkB-deficient animals.

\section{Histogram of Nissl-stained IML-neurons (segments T8-T10)}

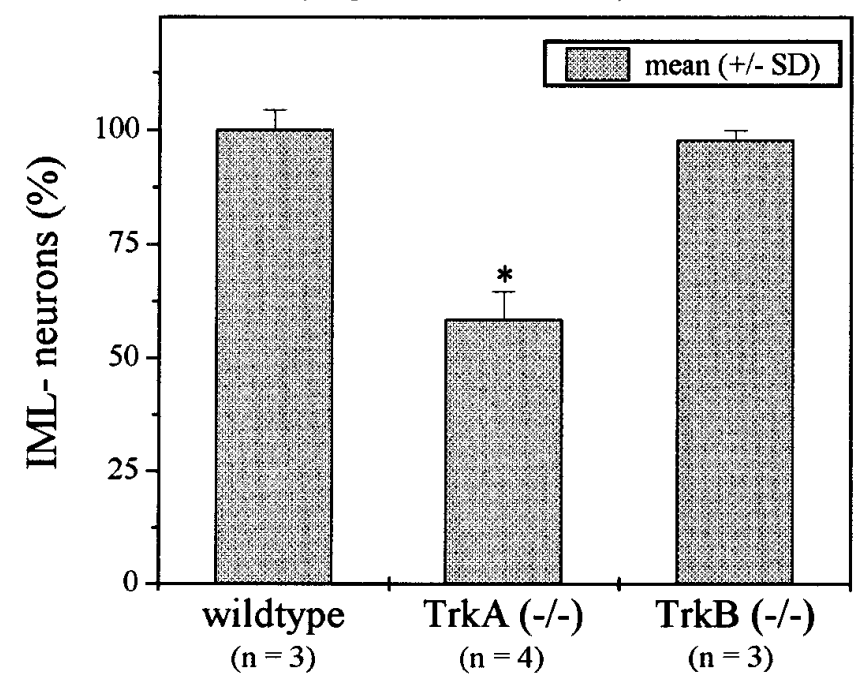

Figure 8. Cell counts of serial transverse sections through spinal cord segments $\mathrm{T} 8-\mathrm{T} 10$ reveal a $41.5 \%$ reduction in IML neuron numbers in TrkA $(-/-)$, as compared with wild-type mice. In TrkB-deficient mice numbers of IML neurons are not affected, $p>0.01$.

(Coupland and Holmes, 1958; Lewis and Shute, 1969; Millar and Unsicker, 1981; Ahonen, 1991). Both pre- and postganglionic noradrenergic sympathetic neurons, as well as chromaffin cells, synthesize and secrete AChE (Lewis and Shute, 1969; Mizobe and Livett, 1980, 1984; Millar and Unsicker, 1981; Hefti et al., 1982; Ahonen, 1991; Parker et al., 1993; Small et al., 1993). The functional implications of TrkA and NGF for the development and maintenance for each of these neural crest derivatives seem to diverge considerably. Both the recent targeted mutations of the TrkA and NGF genes (Crowley et al., 1994; Smeyne et al., 1994) and the early immunosympathectomy experiments (Angeletti et al., 1972) support the essential physiological role of TrkA and retrogradely acting NGF to prevent ontogenetic death of the paravertebral sympathetic neurons [for review, cf. Snider (1994) and Rush et al. (1995)]. In contrast, chromaffin cells of the adrenal medulla do not die on NGF withdrawal by treatment with NGF antibodies (Bode et al., 1986). They do respond, however, to NGF in vitro with neurite outgrowth (Unsicker et al., 1978; Doupe et al., 1985), a moderate increase in survival (Unsicker et al., 1985a,b), induction of TH, and AChE activity (Acheson et al., 1984; Müller and Unsicker, 1986). High-affinity binding sites for NGF on chromaffin cells (Hofmann et al., 1987), TrkA mRNA in newborn rat adrenal medulla (Suter-Crazzolara et al., 1997), and localization of TrkA mRNA in the adult rat (Michael et al., 1995) and mouse adrenal medulla (this study) strongly argue in favor of TrkA being expressed by chromaffin cells. The $62 \%$ reduction in adrenal AChE of TrkA - /- mutants shown in the present study probably can be attributed to reduced AChE activity in both the preganglionic nerve cells and fibers as well as chromaffin cells (compare Figs. 2, 3). AChE has been reported to appear in adrenal nerve terminals and very few chromaffin cells of the rat around birth, gradually increasing toward adulthood (Millar and Unsicker, 1981). This suggests that AChE activity in nerve fibers and chromaffin cells may not have reached adult levels at P7 and P12.

AChE-positive neurons within the IML column sending axons to sympathetic ganglia and adrenal medulla have not been reported to express TrkA. In fact, small interneurons, but not autonomic preganglionic neurons within the rat spinal cord, are immunoreactive for TrkA and express TrkA mRNA (Michael et al., 1995; K. Huber, unpublished observation). Consistent with this observation, NGF, in contrast to fibroblast growth factor-2, ciliary neurotrophic factor, and transforming growth factor- $\beta$, does not rescue IML neurons after ablation of one of their prominent targets, the adrenal medulla (Blottner et al., 1989a,b, 1996). Nonetheless, cell counts of Nissl-stained neurons in the IML of the thoracic spinal cord between segments T8 and T10 in TrkA-deficient and wild-type mice show a $>40 \%$ reduction, reflecting neuron death or shrinkage. From these segments $25 \%$ of the IML neurons are known to project to the adrenal medulla, while the remaining $75 \%$ of the neurons project to prevertebral (coeliac, aorticorenal, superior mesenteric, other) and paravertebral sympathetic ganglia (Strack et al., 1988; Blottner et al., 1996). Our calculations, based on published cell counts and retrograde tracings (Strack et al., 1988), indicate that at least $65 \%$ of the IML neurons projecting to paravertebral ganglia could have disappeared in the TrkA knock-outs (compare Fig. 11). Consistent with this notion, it has been shown in chick embryos that NGF apparently indirectly regulates the survival of these preganglionic sympathetic (the so-called Terni column) neurons within the spinal cord by affecting the survival of their target cells, the postganglionic sympathetic neurons (Oppenheim et al., 1982). Thus, the reduction of $\mathrm{AChE}$ activity in autonomic neurons within the spinal cord of TrkA mutants is most likely attributable to a reduction of enzyme activity in spared IML neurons that project to the adrenal medulla and prevertebral ganglia.

In contrast to postganglionic paravertebral sympathetic neurons, which virtually all disappear in TrkA knock-outs (Smeyne et al., 1994), many aspects of the structure and chemistry of the adrenal medulla appear unchanged. Established markers for chromaffin cells, including various neuropeptides (NPY, met-ENK, somatostatin, galanin), markers of chromaffin granules (chromogranin B, secretogranin II), and vesicular amine transporters (VMAT-1/VMAT-2), are normally expressed and appear not to be changed overtly. As in the wild-type mouse, all chromaffin cells have $\mathrm{TH}$ immunoreactivity, and $\sim 75 \%$ of them express PNMT. In addition to the reduction of AChE activity, a significant decrease in the catecholamine content is the only other hallmark of the 


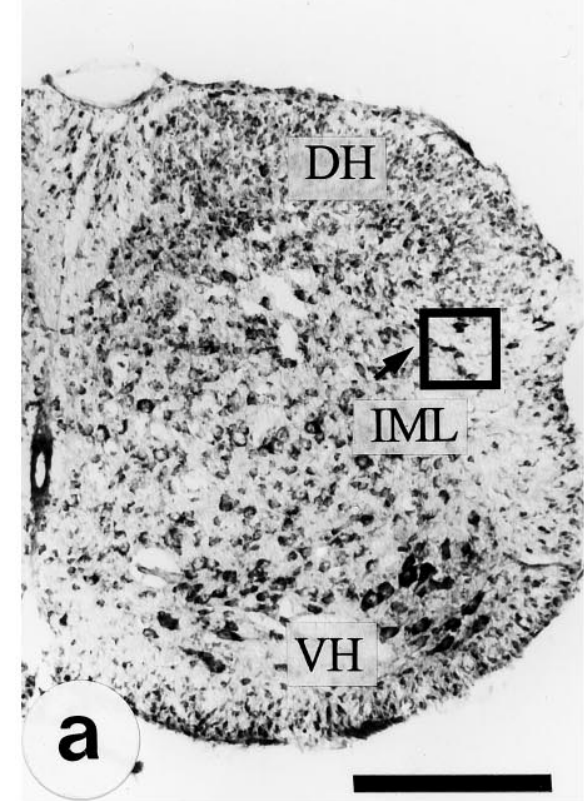

wildtype $(+/+)$

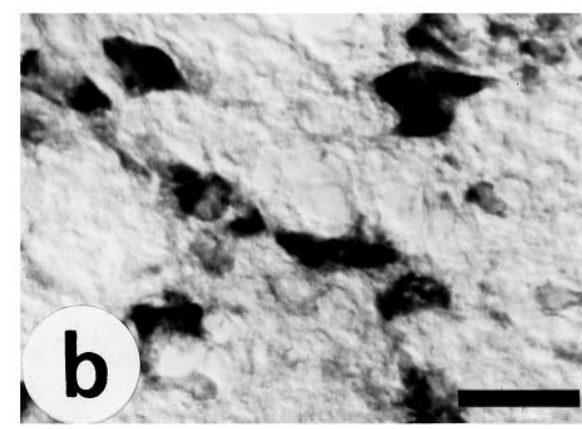

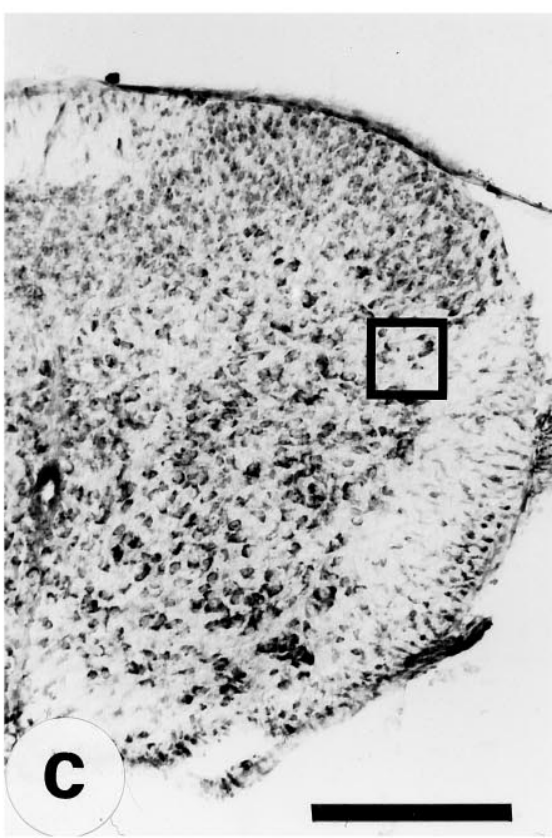

$\operatorname{TrkA}(-/-)$

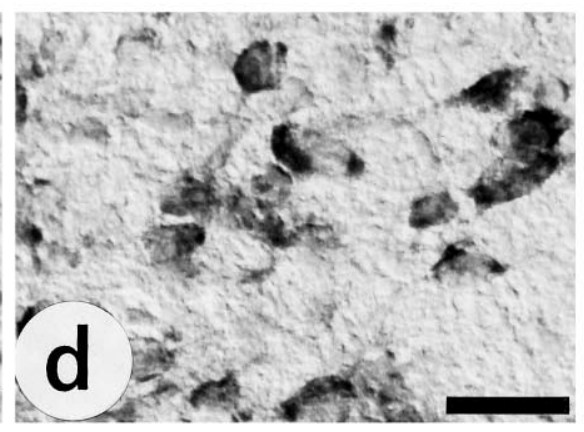

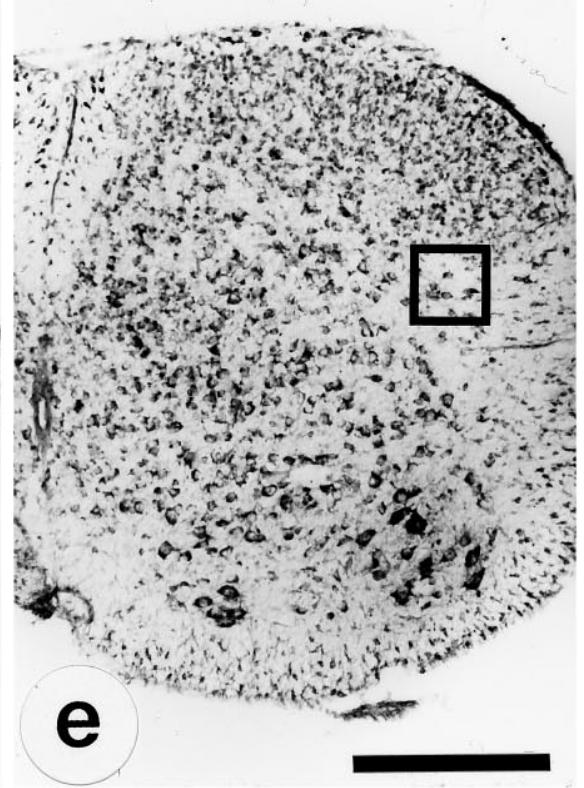

\section{$\operatorname{TrkB}(-/-)$}

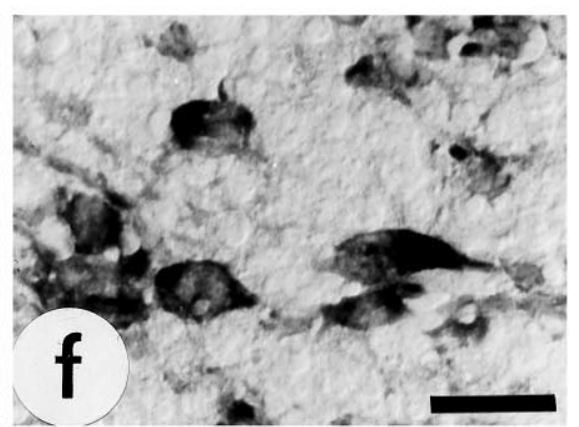

Figure 9. Illustration of the quantitative data presented in Figure 7. Nissl-stained sections from spinal cord segments T8-T10 $(a, c, e)$ and IML $(b, d$, f). $D H$, Dorsal horn; $I M L$, intermediolateral column; $N C$, nucleus centralis; $V H$, ventral horn. Scale bars: $a c, e, 200 \mu \mathrm{m} ; b, d, f, 30 \mu \mathrm{m}$.

TrkA - /- adrenal medullary phenotype. Both phenomena probably are causally linked in that loss of the acetylcholinehydrolyzing enzyme probably accounts for a prolonged and chronic activation of secretion of catecholamines, leading to a partial depletion of catecholamines from the adrenal medulla.

Although a reduction of AChE activity in TrkA-expressing chromaffin cells may be accepted readily as a feature of the TrkA knock-out, the reduction in IML neurons lacking TrkA is more difficult to explain. We assume that the reduction in AChE activity of IML neurons is likely to be a second-order effect. One possible explanation might be that chromaffin cells provide IML neurons with a signal, the expression of which in chromaffin cells can be affected by a TrkA-mediated mechanism. The molecular nature of such a retrograde AChE-regulating messenger remains to be elucidated.

Several lines of evidence indicate that NGF is synthesized within the adrenal gland. NGF mRNA levels shown by Northern blotting in adult rabbit adrenals amount to $\sim 25 \%$ of mRNA levels in the spleen and $\sim 20 \%$ of heart atrium and ventricle, all of which are densely innervated by sympathetic nerves (Shelton and Reichardt, 1984). Furthermore, mouse adrenal explants secrete a neurotrophic activity into their culture medium, which can be blocked by NGF antibodies (Harper, 1976). Taken together, these data suggest that the adrenal gland in vivo is a source of NGF and that chromaffin cells may be the target for the adrenal NGF.

In the spinal cord of TrkA mutants, AChE activity was not only affected in the IML neurons but also with regard to AChEpositive nerve fibers in the superficial and deeper layers of the dorsal horn. These fibers are in their majority axons of dorsal root ganglionic (DRG) neurons, which are virtually all AChE-positive (Gruber et al., 1971). The decrease in AChE staining in the dorsal horn of TrkA mutants is, therefore, likely to reflect the $70-90 \%$ loss of DRG neurons and loss of small sensory afferents in the TrkA knock-out (Smeyne et al., 1994).

AChE activity in spinal cord somatic motoneurons apparently was unaltered in TrkA $(-/-)$, as well as in TrkB $(-/-)$ mice, as compared with wild-type littermates. Somatic motoneurons express TrkB, TrkC, and p75 neurotrophin receptors (Koliatsos et 


\section{Determination of Catecholamines (P6)}

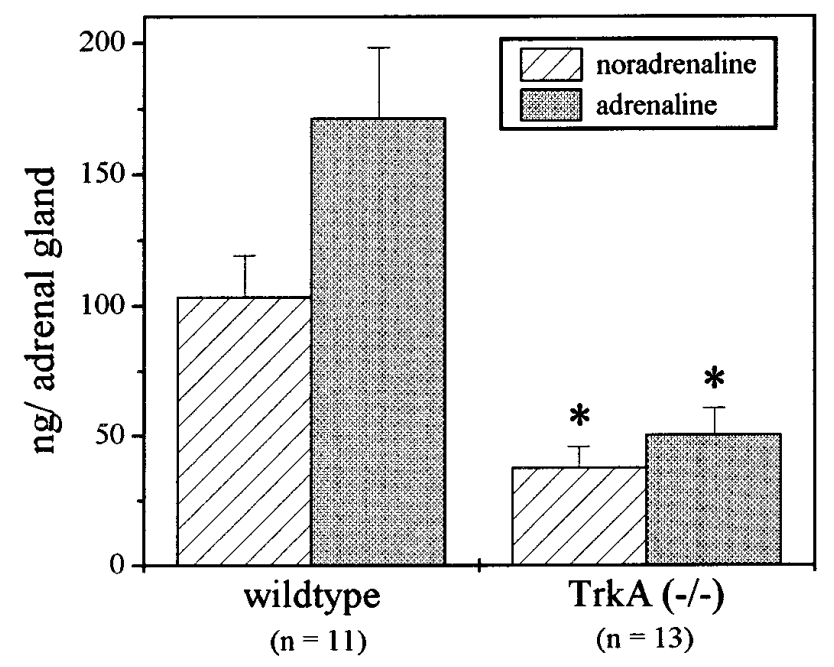

Figure 10. Quantitative determination of catecholamines in P6 adrenal glands reveals significant $\left({ }^{*} p>0.01\right)$ reductions in the noradrenaline $(-65.5 \%)$ and adrenaline $(-70.7 \%)$ content in TrkA $(-/-)$ mice, as compared with wild-type littermates.

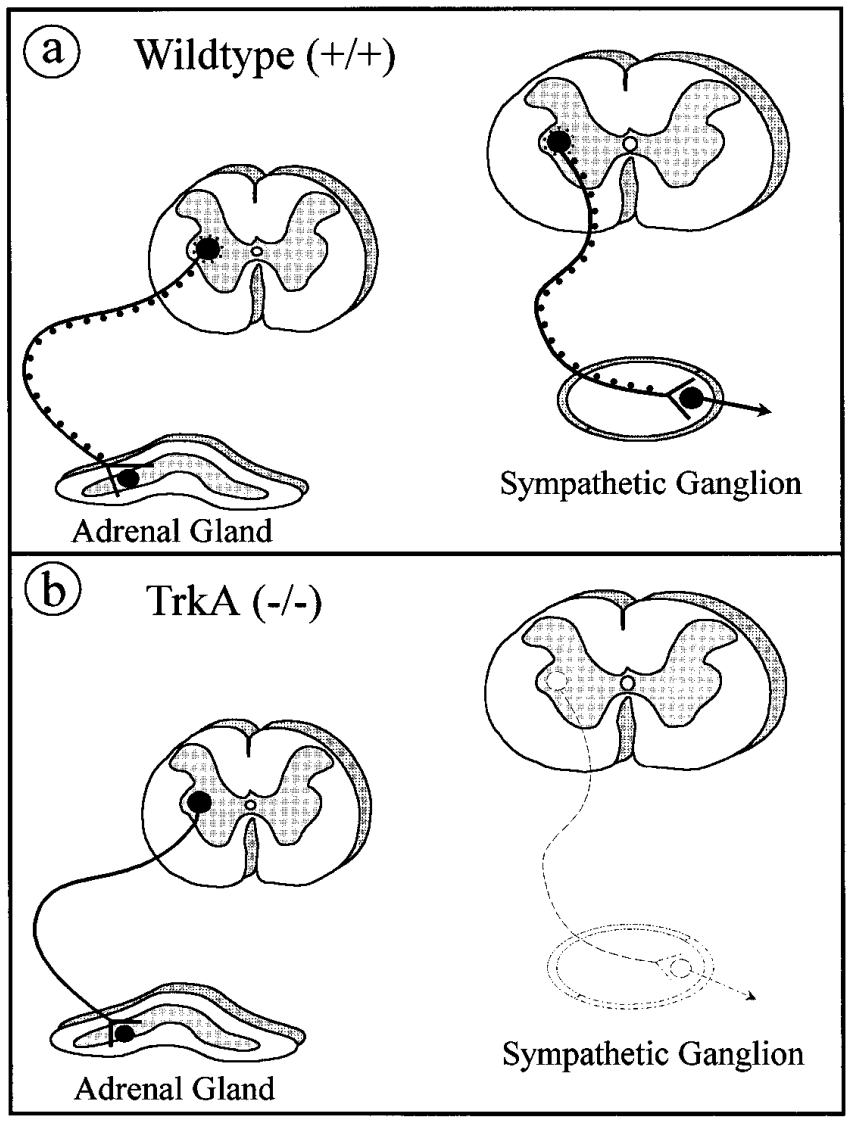

Figure 11. Schematic drawing summarizing the basic findings of this report. Two populations of IML neurons are shown. First, a population of neurons $(a$, right $)$ innervates sympathetic neurons within sympathetic paravertebral ganglia. These neurons express AChE activity (black dots). Their numbers are reduced in TrkA $(-/-)$ mice $(b$, right $)$ because of the loss of paravertebral ganglia. IML neurons innervating chromaffin cells of the adrenal medulla $(a$, left) also have AChE activity. In TrkA (-/-) mice, these neurons do not die but lose AChE activity $(b, l e f t)$. al., 1991; Ernfors et al., 1993; Henderson et al., 1993; Yan et al., 1993). Interestingly, they retrogradely transport not only BDNF (and NT-3) (DiStefano et al., 1992) but, during a limited period of their development, also NGF (Yan et al., 1988), implying the transient presence of p75 and possibly also TrkA. Apparently, none of these properties of motoneurons affects the regulation of AChE activity by NGF or BDNF. The fact that AChE activity of motoneurons was affected neither in TrkA or TrkB mutants underscores the specificity in the TrkA-mediated regulation of AChE within a discrete neuron population, the preganglionic sympathetic neurons.

In conclusion, our data suggest a novel phenotypic feature of TrkA mutants: a loss of AChE activity in the adrenal medulla, in preganglionic nerves to the adrenal medulla, and in autonomic spinal cord neurons (compare Fig. 11). This alteration is specific in that it is not seen in TrkB mutants nor in motoneurons of TrkAand TrkB-deficient mice. It remains to be investigated whether other AChE-expressing neuron populations within the CNS that are coupled to TrkA-expressing systems also are affected in TrkAdeficient animals.

\section{REFERENCES}

Acheson AL, Naujoks K, Thoenen H (1984) Nerve growth factormediated induction in primary cultures of bovine adrenal chromaffin cells: specificity and level of regulation. J Neurosci 4:1771-1780.

Ahonen M (1991) Neurofilament immunoreactivity and acetylcholinesterase activity in the developing sympathetic tissue of the rat. Cell Tissue Res 96:467-478.

Aloe L, Levi-Montalcini R (1979) Nerve growth factor-induced transformation of immature chromaffin cells in vivo into sympathetic neurons: effects of antiserum to nerve growth factor. Proc Natl Acad Sci USA 76:1246-1250.

Andrä J, Lojda Z (1986) A histochemical method for the demonstration of acetylcholinesterase activity using semipermeable membranes. Histochemistry 84:575-579.

Andrä J, van Duijn P (1985) Quantitative aspects of cytochemical methods for acetylcholinesterase studied with a cytochemical model system. Histochemistry 83:443-449.

Angeletti PU, Levi-Montalcini R, Kettler R, Thoenen H (1972) Comparative studies on the effects of nerve growth factor on sympathetic ganglia and adrenal medulla in newborn rats. Brain Res 44:197-206.

Barde YA (1989) Trophic factors and neuronal survival. Neuron 2:1525-1534.

Blottner D, Brüggemann W, Unsicker K (1989a) Ciliary neurotrophic factor supports target-deprived preganglionic sympathetic spinal cord neurons. Neurosci Lett 105:316-320.

Blottner D, Westermann R, Grothe C, Böhlen K, Unsicker K (1989b) Basic fibroblast growth factor in the adrenal gland. Eur J Neurosci 1:471-478.

Blottner D, Wolf N, Lachmund A, Flanders KC, Unsicker K (1996) TGF- $\beta$ rescues target-deprived preganglionic sympathetic neurons in the spinal cord. Eur J Neurosci 8:202-210.

Bode K, Hofmann HD, Müller TH, Otten U, Schmidt R, Unsicker K (1986) Effects of pre- and postnatal administration of antibodies to nerve growth factor on the morphological and biochemical development of the rat adrenal medulla: a reinvestigation. Dev Brain Res 27:139-150.

Bradford MM (1976) A rapid and sensitive method for the quantitation of microgram quantities of protein utilizing the principle of protein-dye binding. Anal Biochem 72:248-254.

Coupland RE, Holmes RL (1958) The distribution of cholinesterase in the adrenal glands of the rat, cat, and rabbit. J Physiol (Lond) 141:97-106.

Crowley C, Spencer SD, Nishimura MC, Chen KS, Pitts-Meek S, Armanini MP, Ling LH, McMahon SB, Shelton DL, Levinson AD, Phillips HS (1994) Mice lacking nerve growth factor display perinatal loss of sensory and sympathetic neurons yet develop basal forebrain cholinergic neurons. Cell 76:1001-1011.

Díaz-Miranda L, Pardo-Reoyo C, García-Arrarás JE (1996) Galanin-like 
immunoreactivity in the echinoderm Holothuria glaberrima. Cell Tissue Res 286:385-391.

DiStefano PS, Friedman B, Radziejewski C, Alexander C, Boland P, Schick CM, Lindsay RM, Wiegand SJ (1992) The neurotrophins BDNF, NT-3, and NGF display distinct pattern of retrograde axonal transport in peripheral and central neurons. Neuron 8:983-993.

Doupe AJ, Landis SC, Patterson PH (1985) Environmental influences in the development of neural derivatives: glucocorticoids, growth factors, and chromaffin cell plasticity. J Neurosci 5:2119-2142.

Ellman GL, Courtney KD, Andres V, Featherstone RM (1961) A new and rapid colorimetric determination of acetylcholinesterase activity. Biochem Pharmacol 7:88-95.

Ernfors P, Rosasrio CM, Merlio JP, Grant G, Persson H (1993) Expression of mRNAs for neurotrophin receptors in the dorsal root ganglion and spinal cord during development and following peripheral or central axotomy. Mol Brain Res 17:217-226.

Faissner A, Teplow DB, Kubler D, Keilhauer G, Kinzel V, Schachner M (1985) Biosynthesis and membrane topography of the cell adhaesion molecule. EMBO J 4:3105-3113.

García-Arrarás JE, Chanconie M, Fontaine-Perús J (1984) In vivo and in vitro development of somatostatin-like immunoreactivity in the peripheral nervous system of quail embryos. J Neurosci 4:1549-1558.

García-Arrarás JE, Chanconie M, Ziller C, Fauquet M (1987) In vivo and in vitro expression of vasoactive intestinal peptide-like immunoreactivity by neural crest derivatives. Brain Res 430:255-265.

García-Arrarás JE, Lugo-Chinchilla AM, Chévere-Colón I (1992) The expression of neuropeptide Y immunoreactivity in the avian sympathoadrenal system conforms with two models of coexpression development for neurons and chromaffin cells. Development (Camb) 115:617-627.

Gruber H, Zenker W, Hohberg E (1971) Untersuchungen über die Spezifität der Cholinesterasen im peripheren Nervensystem der Ratte. Histochemie 27:78-86.

Harper GP, Pearce FL, Vernon CA (1976) Production of nerve growth factor by the mouse adrenal medulla. Nature 261:251-253.

Hefti F, Gnahn H, Schwab ME, Thoenen H (1982) Induction of tyrosine hydroxylase by nerve growth factor and by elevated $\mathrm{K}^{+}$concentrations in cultures of dissociated sympathetic neurons. J Neurosci 2:1554-1566.

Henderson CE, Camu W, Clement M, Gouin A, Poulsen K, Karihaloo M, Rullomas M, Evans T, McMahon SB, Armanini M, Berkemeier L, Phillips H, Rosenthal A (1993) Neurotrophins promote motor neuron survival and are present in embryonic lim bud. Nature 363:266-270.

Hofmann HD, Ebener C, Unsicker K (1987) Age-dependent differences in ${ }^{125}$ I-NGF binding properties of rat adrenal chromaffin cells. J Neurosci Res 18:547-577.

Karnovsky MJ, Roots L (1964) A "direct coloring" thiocholine method for cholinesterase. J Histochem Cytochem 12:219-221.

Kesse WK, Parker TL, Coupland RE (1988) The innervation of the adrenal gland. I. The source of pre- and postganglionic nerve fibers to the rat adrenal gland. J Anat 157:33-41.

Klein R (1994) Role of neurotrophins in mouse neuronal development. FASEB J 8:738-744.

Klein R, Smeyne RJ, Wurst W, Long LK, Auerbach BA, Joyner AL, Barbacid M (1993) Target disruption of the TrkB neurotrophin receptor gene results in the nervous system lesions and neonatal death. Cell 75:113-122.

Klein R, Silos-Santiago I, Smeyne RJ, Lira S, Brambrilla R, Bryant S, Zhang L, Snider WD, Barbacid M (1994) Disruption of the neurotrophin-3 receptor gene TrkC eliminates Ia muscle afferents and results in abnormal movements. Nature 368:249-251.

Koliatsos VE, Shelton DL, Mobley WC, Price DL (1991) A novel group of nerve growth factor receptor-immunoreactive neurons in the ventral horn of the lumbar spinal cord. Brain Res 541:121-128.

Konigsmark BW (1970) Methods for counting neurons. In: Contemporary research methods in neuroanatomy (Nauta WJH, Ebesson SOE, eds), pp 315-340. New York: Springer.

Laird PW, Zijderweld A, Linders K, Rudnicki MA, Jaenisch R, Berns A (1991) Simplified mammalian DNA isolation procedure. Nucleic Acids Res 1:4293.

Layer PG, Willbold E (1995) Novel functions of cholinesterases in development, physiology, and disease. Prog Histochem Cytochem 29:1-94.

Levi-Montalcini R (1987) The nerve growth factor: thirty-five years later. EMBO J 6:2856-2867.

Lewis PR, Shute CCD (1969) An electron microscopic study of cholinesterase distribution in the rat adrenal medulla. J Microsc 89:181-193.

Machida CM, Rodland KD, Matrisian L, Magun BE, Ciment G (1989)
NGF induction of gene encoding transin accompanies neuronal differentiation in PC12 cells. Neuron 2:1587-1596.

Machida CM, Scott JD, Ciment G (1991) NGF induction of metalloproteinase transin/stromelysin in PC 12 cells: involvement of multiple protein kinases. J Cell Biol 114:1037-1048.

Marsh D, Grassi J, Vigny M, Massoulié J (1984) An immunological study of rat acetylcholinesterase: comparison with acetylcholinesterase from other vertebrates. J Neurochem 43:204-213.

Massoulié J, Pezzementi L, Bon S, Krejci E, Valette FM (1993) Molecular and cellular biology of cholinesterases. Prog Neurobiol 41:31-93.

McGuire JC, Greene LA (1978) NGF stimulates incorporation of fucose or glucosamine into an external glycoprotein in cultured rat PC12 pheochromocytoma cells. Cell 15:357-365.

Michael GJ, Kaya E, Averill S, Clary DO, Priestly JV (1995) TrkA immunoreactive neurons in the rat spinal cord. Soc Neurosci Abstr 21:807.

Millar TJ, Unsicker K (1981) Catecholamine-storing cells in the adrenal medulla of the pre- and postnatal rat. Cell Tissue Res 217:155-170.

Mizobe F, Livett BG (1980) Production and release of acetylcholinesterase by a primary cell culture of bovine adrenal medullary chromaffin cells. J Neurochem 35:1469-1472.

Mizobe F, Livett BG (1984) Parallel but separate release of catecholamines and acetylcholinesterase from stimulated adrenal chromaffin cells in culture. J Neurochem 42:1433-1438.

Müller TH, Unsicker K (1981) High-performance liquid chromatography with electrochemical detection as highly efficient tool for studying catecholaminergic systems. I. Quantification of noradrenaline, adrenaline, and dopamine in cultured adrenal medullary cells. J Neurosci Methods 4:39-52.

Müller TH, Unsicker K (1986) Nerve growth factor and dexamethasone modulate synthesis and storage of catecholamines in cultured rat adrenal medullary cells: dependence on postnatal age. J Neurochem 46:516-524.

Oppenheim RW, Maderdrut JL, Wells DJ (1982) Cell death of motoneurons in the chick embryo spinal cord. VI. Reduction of naturally occurring cell death in the thoracolumbar column of Terni by nerve growth factor. J Comp Neurol 210:174-189.

Parker TL (1996) The innervation of the adrenal medulla. In: Autonomic endocrine interactions (Unsicker K, ed), pp 289-314. Reading, UK: Harwood Academic.

Parker TL, Kesse WK, Tomlinson A, Coupland RE (1988) Ontogenesis of preganglionic sympathetic innervation of rat adrenal chromaffin cells. In: Progress in catecholamine research, $\mathrm{Pt} \mathrm{A}$, Basic aspects and peripheral mechanisms (Dahlström A, Belmaker RH, Sandler M, eds), pp 227-232. New York: Liss.

Parker TL, Kesse WK, Mohamed AA, Afework A (1993) The innervation of the mammalian adrenal gland. J Anat 183:265-276.

Prentice HM, Moore SE, Dickson JG, Dohert P, Walsh FS (1987) Nerve growth factor-induced changes in neural cell adhesion molecule $(\mathrm{N}$ CAM) in PC12 cells. EMBO J 6:1859-1863.

Pyner S, Coote JH (1994a) Evidence that sympathetic preganglionic neurones are arranged in target-specific columns in the thoracic spinal cord of the rat. J Comp Neurol 342:15-22.

Pyner S, Coote JH (1994b) A comparison between the adult rat and neonate rat of the architecture of sympathetic preganglionic neurones projecting to the superior cervical ganglion, stellate ganglion, and adrenal medulla. J Auton Nerv Syst 48:153-166.

Rosa P, Hille A, Lee RWH, Zanini A, DeCamilli P, Huttner WB (1985) Secretogranins I and II: two tyrosine-sulfated secretory proteins common to variety of cells secreting peptides by the regulated pathway. J Cell Biol 10:1999-2011.

Rush RA, Mayo R, Zettler C (1995) The regulation of nerve growth factor synthesis and delivery to peripheral neurons. Pharmacol Ther 65:93-123.

Shelton DL, Reichardt LF (1984) Expression of $\beta$-nerve growth factor gene correlates with the density of sympathetic innervation in effector organs. Proc Natl Acad Sci USA 81:7951-7955.

Slotkin TA (1986) Development of the sympathoadrenal axis. In: Developmental neurobiology of the autonomic nervous system (Gootman PM, ed), pp 69-96. Clifton, NJ: Humana.

Small DH (1989) Acetylcholinesterase: zymogens of neuropeptide processing enzymes? Neuroscience 29:241-249.

Small DH, Michaelson S, Marley PD, Friedhuber A, Hocking A, Livett 
BC (1993) Regulation of acetylcholinesterase secretion from perfused bovine adrenal gland and isolated bovine chromaffin cells. J Auton Nerv Syst 42:131-142.

Smeyne RJ, Klein R, Schnapp A, Long LK, Bryant S, Lewin A, Lira SA, Barbacid M (1994) Severe sensory and sympathetic neuropathies in mice carrying a disrupted Trk/NGF receptor gene. Nature 368:246-248.

Snider WD (1994) Functions of the neurotrophins during nervous system development: what the knock-outs are teaching us. Cell 77:627-638.

Strack AM, Sawyer WB, Marubio LM, Loewy AD (1988) Spinal origin of sympathetic preganglionic neurons in the rat. Brain Res 455:187-191.

Suter-Crazzolara C, Lachmund A, Arab S, Unsicker K (1997) Expression of neurotrophins and their receptors in the developing and adult rat adrenal gland. Mol Brain Res 43:351-355.

Thoenen H (1972) Surgical, immunological, and chemical sympathectomy. Their application in the investigation of the physiology and pharmacology of the sympathetic nervous system. In: Handbook of experimental pharmacology (Blaschko H, Muscholl E, eds), pp 813844. Berlin: Springer.
Thoenen H, Barde YA (1980) Physiology of nerve growth factor. Physiol Rev 60:1284-1335.

Unsicker K (1993) The chromaffin cell: paradigm in cell, developmental, and growth factor biology. J Anat 183:207-221.

Unsicker K, Kirsch B, Otten U, Thoenen H (1978) Nerve growth factor induces fiber outgrowth from isolated rat adrenal chromaffin cells: impairment by glucocorticoids. Proc Natl Acad Sci USA 75:3498-3502.

Unsicker K, Skaper SD, Varon S (1985a) Neurotrophic and neuritepromoting factors: effects on early postnatal chromaffin cells from rat adrenal medulla. Dev Brain Res 17:117-129.

Unsicker K, Skaper SD, Varon S (1985b) Development changes in the response of rat chromaffin cells to neurotrophic and neurite-promoting factors. Dev Biol 111:425-433.

Yan Q, Snider WD, Pinzone JJ, Johnson EM (1988) Retrograde transport of nerve growth factor (NGF) in motoneurons of developing rats: assessment of potential neurotrophic effects. Neuron 1:335-343.

Yan Q, Elliot J, Snider WD (1993) Influences of neurotrophins on mammalian motoneurons in vivo. J Neurobiol 24:1555-1577. 